\title{
KETELADANAN GURU DAN PENDIDIKAN DALAM KELUARGA TERHADAP KEPRIBADIAN MUSLIM SISWA DI MTS PONDOK PESANTREN AL-HUSAINY KOTA BIMA
}

\author{
Farizal Marliu, Otong Surasman, Taufan \\ Institut PTIQ Jakarta, DKI Jakarta, Indonesia \\ Email: Farizal.m.s@gmail.com
}

\begin{abstract}
Abstrak
Penelitian ini bertujuan untuk menentukan data empiris yang terkait dengan teladan guru dan kepribadian pendidikan siswa muslim secara terpisah atau bersama-sama. Penulis menggunakan metode survey data kuantitatif korelasional yang diperoleh dari siswa Madrasah Tsanawiyah/MTs Pondok Pesantren Al-Husainy Kota Bima, NTB. Sampel penelitian sebanyak 120 responden tahun ajaran 2017-2018.Pengumpulan data menggunakan observasi, dokumentasi, dan kuesioner.Jenis analisis ini menggunakan analisis korelasi dan regresi dijelaskan secara deskriptif. Hasil penelitian, pengaruh yang signifikan antara kepribadian guru-siswa teladan Muslim ditunjukkan oleh besarnya koefisien korelasi dan koefisien determinasi berarti bahwa setiap peningkatan satu unit skor keteladanan guru mempengaruhi peningkatan Skor Kepribadian Siswa muslim. Ada pengaruh yang signifikan antara Pendidikan dalam Keluarga dengan Kepribadian Muslim, yang berarti bahwa setiap peningkatan dalam satu unit Pendidikan dalam Skor Keluarga mempengaruhi peningkatan skor Kepribadian Muslim sebesar 0,360, itu berarti bahwa setiap peningkatan dalam satu unit nilai pendidikan dalam keluarga mempengaruhi peningkatan skor lepribadian muslim siswa. Ada pengaruh signifikan yang ditunjukkan nilai probabilitas. Nilai koefisien korelasi kedua variabel adalah 0,633 dan koefisien determinasi adalah 40,1\%, yang berarti bahwa peningkatan satu unit skor dari model guru dan pendidikan di keluarga bersama-sama meningkatkan skor kepribadian siswa.
\end{abstract}

Kata Kunci: Keteladan, Pendidikan Keluarga, Kepribadian Muslim.

\section{Pendahuluan}

$\mathrm{P}$ endidikan dapat diartikan sebagai proses membimbing anak menjadi dewasa dan mampu memikul tanggung jawab atas segala perbuatan dan mandiri. ${ }^{1}$ Anak dilahirkan dalam keadaan lemah dan suci/fitrah, sedangkan alam sekitar memberi warna terhadap nilai hidup atas pendidikan

agama. ${ }^{2}$ Anak tidak tumbuh dan berkembang dengan sendiri tanpa adanya bantuan orang lain, untuk membimbing, mendorong, mengarahkan sehingga berbagai potensi dapat tumbuh, dan berkembang secara wajar dan optimal, sehingga dapat

${ }^{1}$ Zuhairini, dkk., Filsafat Pendidikan Islam, (Jakarta: Bumi Aksara, 1995), 92.

${ }^{2}$ Ibid., $170-171$. 
berguna dan berhasil. ${ }^{3}$ Setiap individu memiliki kemampuan yang berbeda dalam mengembangkan potensi anak.Hal tersebut terjadi karena setiap individu memiliki kepribadian yang berbeda. Anak akan melihat kepribadian sosok yang mendampinginya, sehingga soosok figure agar terbentuk dan anak akan mengikuti sosok figure tersebut.

Istilah kepribadian berasal dari bahasa Inggris "personality" dan juga ada yang menyebut "individuality".Kepribadian berasal dari kata pribadi yaitu manusia sebagai perseorangan, mendapat awalan ke dan akhiran an, sehingga menjadi kepribadian yaitu keadaan manusia sebagai perseorangan dan keseluruhan sifat-sifat yang merupakan watak. ${ }^{4}$ Kepribadian merupakan cermin dari seluruh tingkah laku seseorang. ${ }^{5}$ Kepribadian adalah sistem-sistem psikofisik yang dinamis dari diri individu yang turut menentukan cara-caranya yang unik (khas) dalam menyesuaikan dirinya dengan lingkungannya. ${ }^{6}$ Kepribadian dari segi agama dikenal kepribadian muslim, yaitu identitas yang dimiliki seseorang sebagai ciri khas dari keseluruhan tingkah laku sebagai muslim, baik tingkah laku secara lahiriyah maupun batiniah. ${ }^{7}$ Tingkah laku lahiriyah seperti cara berkata, berjalan, berpakaian, makan, minum, berhadapan dengan teman, tamu dan lainlain sikap batinah seperti penyabar, ikhlas, tidak dengki, tidak dendam, dan lainlain. Kepribadian muslim adalah kepribadian yang seluruh aspek-aspeknya yakni baik tingkah laku luarnya kegiatan-kegiatan jiwanya, maupun filsafat hidup dan kepercayaannya menunjukkan pengabdian kepada Tuhan. ${ }^{8}$

Kepribadian merupakan unsur psikis, fisik, sikap, dan prilaku dari individu. Individu yang memiliki kepribadian baik atau berakhlak mulia akan dianggap baik, sebaliknya bila seseorang melakukan sikap yang tidak baik menurut pandangan masyarakat, maka individu dianggap tidak mempunyai akhlak yang mulia. Kepribadian dapat menentukan apakah guru menjadi pendidik dan pembina yang baik, sebagai cerminan bagi anak terutama bagi anak yang sekolah dasar dan mereka yang sedang mengalami kegoncangan jiwa (tingkat remaja). ${ }^{9}$ Kepribadian muslim merupakan tujuan akhir dari pendidikan Islam.Kita bangsa Indonesia yang telah memiliki filsafat hidup Pancasila, yang sekaligus juga menjadi filsafat pendidikan Nasional, mempunyai cita-cita membangun dan

${ }^{3}$ Ibid., 94.

${ }^{4}$ Departemen Pendidikan dan Kebudayaan, Kamus Besar Bahasa Indonesia, (Jakarta: Balai Pustaka, Edisi ke II, 1994), 788.

${ }^{5}$ Jalaluddin, Teologi Pendidikan, (Jakarta: Raja Grafindo Persada, 2001), 172

${ }^{6}$ Zuhairini dkk, Filsafat Pendidikan Islam....,187.

${ }^{7}$ Jamaluddin Miri, Pendidikan Anak dalam Islam, (Jakarta Pustaka Amani, 2002), 66

${ }^{8}$ Ahmad D. Marimba, Pengantar Filsafat Pendidikan Islam, (Bandung: PT Al-Ma'arif, 1980), 68.

${ }^{9}$ Syaiful Bahri Djamarah, Guru dan Anak Didik dalam Interaksi Edukasi, (Jakarta: Rineka Cipta, 2000), 40. 
membentuk kepribadian bangsa yaitu kepribadian manusia seutuhnya yang memiliki ciri sebagai bangsa Indonesia. ${ }^{10}$

Kepribadian manusia terkandung berbagai sifat hewani yang tercermin dari berbagai kebutuhan fisik yang harus dipenuhi demi kelangsungan hidupnya. Selain itu terdapat pula sifat-sifat malaikat yang tercermin dari kerinduan spiritualnya untuk mengenal Allah, beriman, menyembah, dan memuji-Nya. Jadi, kepribadian muslim adalah kepribadian seseorang yang mencerminkan suatu ciri khas seorang muslim yang sesuai dengan ajaran-ajaran Islam.Terkadang antara dua aspek kepribadian ini terjadi konflik seperti diisyaratkan dalam QS. AnNaziat/79: $37-42 .^{11}$

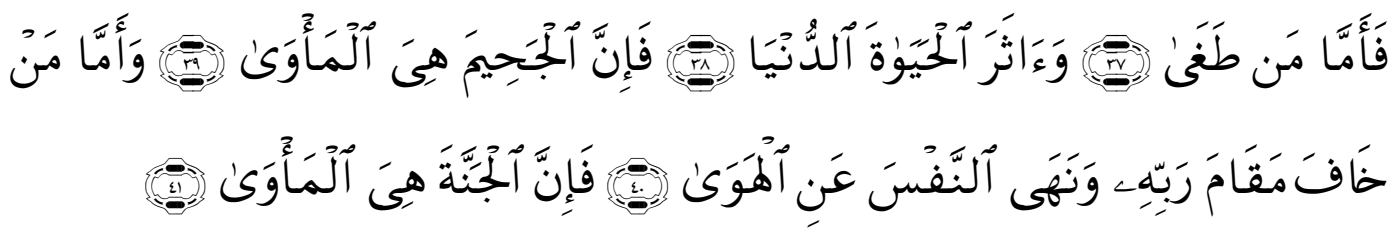

Terjemahannya: "Adapun orang yang melampaui batas, dan lebih mengutamakan kehidupan dunia, maka sesungguhnya nerakalah tempat tinggal(nya). Dan adapun orang yang takut kepada kebesaran Tuhannya dan menahan diri dari keinginan hawa nafsunya, maka sesungguhnya surgalah tempat tinggal. ${ }^{12}$

Pendidikan dalam madrasah menekankan pada ajaran Islam. Pada prinsipnya siswa melihat kepribadian yang dimiliki para guru berdasarkan ajaran Islam. Kepribadian tersebut dikenal dengan kepribadian muslim. Siswa melihat sosok guru yang memiliki kepribadian muslim yang baik untuk diteladani, sehingga siswa dapat mengikutinya.

\section{Urgensi Keteladanan Guru Dalam Dalam Pendidikan Kepribadian Muslim Siswa}

Kedudukan guru dilingkup satuan pendidikan menjadi kunci sukses penyelenggaraan pendidikan. Secara etimologis, terdapat ragam pengertian yang disemat pada profesi seorang guru. Dalam bahasa Inggris ditemukan beberapa kata yang lazim maknanya disebut guru, yaitu; teacher, tutor, instructor, dan educator. Berdasarkan penjelasan Kamus Webster's, teacher diartikan seseorang yang mengajar; tutor diartikan seseorang guru yang memberikan pengajaran terhadap peserta didik; instructor diartikan seseorang yang mengajar; dan educator, diartikan dengan seseorang yang mempunyai tanggung jawab pekerjaan mendidik yang lain. Sedangkan dalam Kamus Besar Bahasa Indonesia, guru

\footnotetext{
${ }^{10}$ Syaiful Bahri Djamarah, Guru dan Anak Didik dalam Interaksi Edukasi, ..., 186-187.

${ }^{11}$ M. Usman Najati, Al-Qur'an dan Ilmu Jiwa, (Bandung: Pustaka, 1997), 240.

${ }^{12}$ Departemen Agama RI, Al-Qur'an Tajwid dan Terjemahannya, (Solo Banjarsari: ABYAN, 2014), 583.
} 
dipersepsikan sebagai orang yang pekerjaannya (mata pencahariannya) mengajar. ${ }^{13}$ Guru sering pula dikonotasikan sebagai kepanjangan dari kata "digugu dan ditiru". Digugu artinya segala sesuatu yang disampaikan oleh guru senantiasa dipercaya, didengar, diikuti, dan diyakini sebagai sebuah kebenaran oleh semua muridnya, sedangkan ditiru artinya seorang guru menjadi suri tauladan bagi semua muridnya, mulai dari cara berpikir, cara berbicara, hingga cara berperilaku sehari-hari, dengan kata lain figur guru harus menjadi contoh. Ungkapan lain tentang guru juga dikenal dengan sebuah pribahasa yang berbunyi "guru kencing berdiri, murid kencing berlari". Peribahasa tersebut memiliki makna bahwa semua perilaku guru menjadi panutan bagi anak didiknya. ${ }^{14}$

Gambaran keteladan sifat-sifat seorang guru juga disempaikan oleh $\mathrm{Ki}$ Hajar Dewantara dalam M. Sukarjo, dengan pernyataan filosofisnya yang memaknai guru dengan sebutan ing ngarso sung tulado, ing madya mangun karso, dan tut wuri handayani. Falsafah ing ngarso sung tulado bermakna seorang guru hendaknya menjadi teladan yang baik bagi murid-muridanya. Ing madya mangun karso menyiratkan seorang guru harus terus membuat inovasi dalam pembelajaran. Tut wuri Handayani menegaskan bahwa seorang pendidik harus dapat membangkitkan motivasi, memberikan dorongan pada anak didiknya untuk terus maju, berkarya, dan berprestasi. Hal yang sama, juga diungkap pujangga kenamaan sekaliber Khalil Gibran, dalam syairnya menjelaskan terkait pentingannya keteladanan sifat kepribadian dalam diri seorang guru, sebagai cerminan diri dalam melaksanakan tugas pembelajaran bagi anak didiknya. Menurutnya, siapapun orang yang ingin mengabdikan dirinya untuk menjadi guru, keteladan diri merupakan indikator utama yang harus dimiliki. Keteladan harus menjadi kunci pengajaran, dengan keteladanan seorang guru akan mendapatkan penghormatan dan kemulian. ${ }^{15}$

Keteladanan guru sangat penting karena apa yang dilakukan oleh para guru baik tingkah laku, perkataan dan perbuatan akan mendapatkan perhatian dari peserta didik. Hal ini karena pendidik merupakan figur terbaik dalam pandangan anak, sopan santun, perbuatan, disadari atau tidak akan ditiru anak didik. ${ }^{16}$ Keteladanan pendidik akan muncul gejala identifikasi positif yaitu penyamaan diri dengan orang yang ditiru. Identifikasi positif penting dalam pembentukan kepribadian. ${ }^{17}$ Dalam Islam, Rasulullah SAW telah menjadi manusia terbaik yang

${ }^{13}$ Lihat Umar, Pengantar Profesi Keguruan (Cet. I; Jakarta: PT Rajagrafindo Persada, 2019), 7-8.

${ }^{14}$ Ibid.

${ }^{15}$ Ibid, 35 .

${ }^{16}$ Abdullah Nashih Ulwan, Pendidikan Anak Dalam Islam, (Jakarta: Pustaka Amani, 1995), 2.

${ }^{17}$ Ahmad D. Marimba, Pengantar Filsafat Pendidikan Islam, (Bandung: PT Al-Ma'arif, 1980), 85. 
bertugas untuk menerjemahkan Al-Qur'an pada tingkah laku yang nyata dihadapan manusia yang menjadikan beliau sebagai figur sentral yang dicontoh dan diteladani. Oleh karena itu Islam mengakui bahwa cara yang paling ampuh untuk mendatangkan kesuksesan terbesar dan lebih berdaya guna dalam menyampaikan nilai-nilai ajaran Islam adalah suri tauladan. Dengan demikian diduga kuat ada korelasinya antara keteladanan guru dengan kepribadian muslim peserta didik. Siswa mendapatkan sosok figure keteladanan pribadi muslim, tidak saja di sekolah tetapi mendapatkan juga di lingkungan keluarga. Oleh karena itu orangtua juga diharapkan memberikan contoh teladan bagi siswa ketika berada dalam lingkungan keluarga. Akhirnya, siswa akan mendapatkan sosok teladan pribadi muslim yang sempurna karena di sekolah dan lingkungan keluarga bekerja sama, sehingga sosok teladan menjadi kuat dalam pemikiran sisiwa. Lingkungan keluarga merupakan pendidikan pertama yang berpengaruh terhadap perilaku dan perkembangan anak didik.Hasil-hasil yang diperoleh anak dalam keluarga menentukan pendidikan anak itu selanjutnya, baik di sekolah maupun dalam masyarakat. ${ }^{18}$ Hal ini dilakukan agar anak tidak goyah imannya dalam masyarakat, karena telah mendapatkan modal yang kokoh sebagai hasil dari proses pembelajarannya di lingkup satuan pendidikan.

\section{Faktor Pendukung Keteladanan Guru Dalam Pendidikan Kepribadian Muslim Siswa}

Terdapat sujumlah faktor pendukung dalam pelaksanaan pendidikan dalam lingkungan keluarga yaitu harus ada usaha dalam mengembangkan potensi jasmani dan rohani, usaha didasarkan pada ajaran Agama Islam, dan usaha bertujuan agar anak memiliki kepribadian utama menurut agama Islam. ${ }^{19}$ Faktorfaktor penghambat dalam pelaksanaan pendidikan keluarga muslim, yaitu factor yang berasal dalam keluarga itu sendiri, faktor berasal dari luar lingkungan keluarga. Biasanya factor didalam keluarga berasal dari problem orang tua seperti pendidikan yang rendah, orangtua sibuk. ${ }^{20}$ Faktor dari luar lingkungan yang menghambatbiasanya seperti lingkungan masyarakat, media masa yang mudah dijangkau siswa yang belum dapat disortir mana yang boleh dan tidak boleh diikuti. ${ }^{21}$ Orang tua berkontribusi dalam mengatasi hambatan pelaksanaan pendidikan dengan memberikan pembinaan kepada siswa secara terbuka dan kasih saying, orang tua meluangkan waktu dalam keluarga dan memberikan kebutuhan

\footnotetext{
${ }^{18}$ Ngalim Purwanto, Ilmu Pendidikan: Teoritis dan Praktis, (Bandung: Remaja Karya, 1988), 85-86.

${ }^{19}$ Mujamil Qomar,,Meniti Jalan Pendidikan Islam, (Yogyakarta: Pustaka Pelajar, 2003), 380.

${ }^{20}$ Djamarrah,Syaifulbahri.Guru dan Anak Didik Dalam Interaksi Edukatif, (Jakarta: Rineka Cipta, 2000), 87.

${ }^{21}$ Mukhotim El Moekry, Membina Anak Beraqidah Kokoh, (Jakarta: Wahyu Press, 2004), 34.
} 
anak, orang tua belajar untuk memahami betul-betul ilmu pengetahuan agama Islam, orang tua menjadi suri tauladan yang baik, orang tua menyediakan alat pendidikan atau fasilitas-fasilitas untuk siswa, dan orang tua menemani siswa belajar dirumah. Keteladanan guru juga diharapkan sebagai contoh agar siswa dapat mengcopi keteladanan sehingga menciptakan siswa yang berkualitas, dan orang tua juga ikut berpartisipasi dalam memberikan keteladanan saat anak berada di rumah. Dengan demikian peranan dan tanggung jawab orang tua dalam keluarga untuk mengembangkan potensi yang ada pada anak. Pendidikan Agama terutama Pendidikan Agama Islam harus diprioritaskan dalam lingkungan keluarga. Agar anak selalu siap menghadapi masalah yang ia hadapi apalagi dengan perkembangan teknologi dan informasi yang semakin maju.Untuk itu orang tua perlu melaksanakan pendidikan Agama Islam dalam keluarga untuk mengembangkan potensi dan membentengi anak dari pengaruh globalisasi.

\section{Metode Penelitian}

Penelitian terkait keteladanan guru dan pendidikan dalam keluarga terhadap kepribadian muslim siswa secara terpisah maupun simultan merupakan jenis penelitian kuantitatif metode survei dengan pendekatan korelasional. Jenis analisis yang digunakan adalah analisa korelasi dan regresi yang dijabarkan secara deskriptif.Sampel penelitian ini adalah sebanyak 120 responden Siswa sekolah Madrasah Tsanawiyah/MTs Pondok Pesantren Al-Husainy Kota Bima dari total 170 populasi pada semester ganjil tahun ajaran 2017-2018. Pengumpulan data dilakukan dengan menggunakan teknik observasi, dokumentasi, dan angket/kuesioner. Teknik analisis data meliputi editing, skoring, tabulating. Dalam menganalisis tentang penelitian ini, peneliti menggunakan deskriptif kualitatif, analisis statistika yang dapat dilihat dalam diskripsi tabel hitungan variabel berikut ini:

Tabel 1. Perhitungan Varaibel Penelitian

\begin{tabular}{|c|c|c|c|c|}
\hline No. & Variabel & Skor Rata-Rata & \% & Kategori \\
\hline 1. & $\begin{array}{c}\text { Kepribadian } \\
\text { Muslim Siswa }\end{array}$ & 83.38 & $83.38 \%$ & Tinggi \\
\hline 2. & $\begin{array}{c}\text { Keteladanan } \\
\text { Guru }\end{array}$ & 128,27 & $85,53 \%$ & Baik \\
\hline 3. & $\begin{array}{c}\text { Pendidikan } \\
\text { dalam Keluarga }\end{array}$ & 132,23 & $88 \%$ & Baik \\
\hline
\end{tabular}

Jika dilihat dari skor setiap variabel, pendidikan dalam keluarga memiliki skor yang paling tinggi dari semua variabel, yaitu dengan nilai rata-rata 132.23 atau $88 \%$. Hal ini menandakan bahwa pendidikan dalam keluarga dalam kategori baik, artinya adanya kontribusi keluarga dalam membantu menumbuhkan, 
meningkatkan kepribadian muslim, tidak hanya tugas guru disekolah tetapi pihak keluarga juga ikut membantu.

\section{Hasil Penelitian}

Deskriptif Data Variabel Keribadian Muslim Siswa MTs Pondok Pesantren Al-Husainy Kota Bima

Gambaran data deskriptif variabel Kepribadian Muslim Siswa yangdiperoleh dari hasil penelitian, menunjukkan bahwa dengan jumlah responden 120 orang, skor rata-rata 83,38 atau sama dengan 83,38\% dari skor idealnya yaitu 100, dalam kategori tinggi yang dapat dilihat dalam uraian tabel 2 terkait deskriptif Varibel Kepribadian Muslim siswa berikut ini:

Tabel 2. Data Deskriptif Variabel Kepribadian Muslim Siswa

\begin{tabular}{|c|l|r|}
\hline No. & \multicolumn{1}{|c|}{ Aspek Data } & \multicolumn{1}{|c|}{ Skor } \\
\hline 1. & N (Jumlah responden) & 120 \\
\hline 2. & Mean (rata-rata) & 83.38 \\
\hline 3. & Std. Error of Mean (kesalahan rata-rata standar) & .489 \\
\hline 4. & Median (nilai tengah) & 83.00 \\
\hline 5. & Mode (nilai yang sering muncul) & 83 \\
\hline 6. & Std. Deviation (simpang baku) & 5.361 \\
\hline 7. & Variance (Varian) & 28.743 \\
\hline 8. & Range (rentang) & 27 \\
\hline 9. & Minimum (skor terkecil) & 70 \\
\hline 10. & Maximum (skor terbesar) & 97 \\
\hline 11. & Sum (jumlah) & 10006 \\
\hline
\end{tabular}

Deskriptif Data Keteladan Para Guru dilingkup MTs Pondok Pesantren AlHusainy Kota Bima

Gambaran deskriptif variabel Keteladanan Guru yangdiperoleh dari hasil penelitian, menunjukkan bahwa dengan jumlah responden 120 orang, skor rata-rata 128,27 atau sama dengan $85,53 \%$ dari skor idealnya yaitu 150 , yang dapat dilihat dalam uraian Berdasarkan Tabel 3 berikut ini:

Tabel 3. Data Deskriptif Variabel Keteladanan Guru

\begin{tabular}{|c|l|r|}
\hline No. & \multicolumn{1}{|c|}{ Aspek Data } & \multicolumn{1}{|c|}{ Skor } \\
\hline 1 & N (Jumlah responden) & 120 \\
\hline 2 & Mean (rata-rata) & 128.27 \\
\hline 3 & Std. Error of Mean (kesalahan rata-rata standar) & .962 \\
\hline 4 & Median (nilai tengah) & 129.50 \\
\hline 5 & Mode (nilai yang sering muncul) & 134 \\
\hline
\end{tabular}




\begin{tabular}{|c|l|r|}
\hline 6 & Std. Deviation (simpang baku) & 10.541 \\
\hline 7 & Variance (Varian) & 111.105 \\
\hline 8 & Range (rentang) & 49 \\
\hline 9 & Minimum (skor terkecil) & 100 \\
\hline 10 & Maximum (skor terbesar) & 149 \\
\hline 11 & Sum (jumlah) & 15392 \\
\hline
\end{tabular}

Deskriptif Data Variabel Skor Variabel Pendidikan Dalam Keluarga Siswa MTs Pondok Pesantren Al-Husainy Kota Bima

Gambaran data deskriptif variabel Pendidikan Dalam Keluarga (X2) yangdiperoleh dari hasil penelitian, menunjukkan bahwa dengan jumlah responden 150 orang, skor rata-rata 132,23 atau sama dengan $88 \%$ dari skor idealnya yaitu 150, dapat dlita dalam Table 4 sebagai berikut:

Tabel 4. Data Deskriptif Variabel Skor Variabel Pendidikan Dalam Keluarga

\begin{tabular}{|c|l|r|}
\hline No. & \multicolumn{1}{|c|}{ Aspek Data } & \multicolumn{1}{|c|}{ Skor } \\
\hline 1. & N (Jumlah responden) & 120 \\
\hline 2. & Mean (rata-rata) & 132.23 \\
\hline 3. & Std. Error of Mean (kesalahan rata-rata standar) & .860 \\
\hline 4. & Median (nilai tengah) & 133.00 \\
\hline 5. & Mode (nilai yang sering muncul) & 136 \\
\hline 6. & Std. Deviation (simpang baku) & 9.422 \\
\hline 7. & Variance (Varian) & 88.769 \\
\hline 8. & Range (rentang) & 44 \\
\hline 9. & Minimum (skor terkecil) & 106 \\
\hline 10. & Maximum (skor terbesar) & 150 \\
\hline 11. & Sum (jumlah) & 15868 \\
\hline
\end{tabular}

Deskriptif Data Korelasi Sederhana Keteladan Guru dengan Kepribadian Muslim Siswa MTs Pondok Pesantren Al-Husainy Kota Bima

Berdasarkan tabel nilai koefisien korelasi di atas, analisis hubungan/korelasi terhadap pasangan-pasangan data dari variabel $\mathrm{X}_{1}$ dengan $\mathrm{Y}$ tersebut menghasilkan koefisien korelasi r product-moment sebesar 0,549. Telah signifikansi terhadap nilai koefisien korelasi tersebut diperoleh nilai Sig. (1tailed $)=0.00$, Karena nilai Sig. (1-tailed) $0.00<0,05$ berarti Dengan demikian, maka Ho ditolak dan Hi diterima, yang berarti bahwa terdapat pengaruh positif dan sangat signifikan antara Keteladanan Guru terhadap Kepribadian Muslim Siswa, dapat dilihat dalam jabaran tabel 5 sebagai berikut: 
Tabel 5 . Korelasi Sederhana Keteladan Guru dengan Kepribadian Muslim Siswa Correlations

\begin{tabular}{|l|l|r|r|}
\hline \multicolumn{2}{|c|}{ Indikator Aspek } & \multicolumn{1}{|c|}{$\begin{array}{c}\text { Kepribadian } \\
\text { Muslim Siswa }\end{array}$} & \multicolumn{1}{c|}{$\begin{array}{c}\text { Keteladanan } \\
\text { Guru }\end{array}$} \\
\hline $\begin{array}{l}\text { Kepribadian } \\
\text { Muslim Siswa }\end{array}$ & $\begin{array}{l}\text { Pearson } \\
\text { Correlation }\end{array}$ & 1 & $\mathbf{. 5 4 9}^{* *}$ \\
\cline { 2 - 4 } & Sig. (1-tailed) & 120 & .000 \\
\cline { 2 - 4 } & $\mathrm{N}$ & $\mathbf{. 5 4 9}$ & 120 \\
\hline $\begin{array}{l}\text { Keteladanan } \\
\text { Guru }\end{array}$ & $\begin{array}{l}\text { Pearson } \\
\text { Correlation }\end{array}$ & .000 & 1 \\
\cline { 2 - 4 } & Sig. (1-tailed) & 120 & 120 \\
\cline { 2 - 4 } & $\mathrm{N}$ & & \\
\hline$* *$ Correlation is significant at the 0.01 level (1-tailed). \\
\hline
\end{tabular}

Deskriptif Data Korelasi Sederhana Pendidikan dalam Keluarga dengan Kepribadian Muslim Siswa MTs Pondok Pesantren Al-Husainy Kota Bima

Berdasarkan tabel nilai koefisien korelasi di atas, analisis hubungan/korelasi terhadap pasangan-pasangan data variabel tersebut menghasilkan koefisien korelasi $r$ product-moment sebesar 0,632. Telah signifikansi terhadap nilai koefisien korelasi tersebut diperolehnilai Sig. (1-tailed) $=0.000$, Karena nilai Sig. (1-tailed) $0.000<0,05$ berarti Telaah signifikansi terhadap nilai koefisien korelasi tersebut diperoleh nilai Sig. $(1$-tailed $)=0.00$, Karena nilai Sig. (1-tailed) $0.00<0,05$ berarti Dengan demikian, maka Ho ditolak dan Hi diterima, yang berarti bahwa terdapat pengaruh positif dan sangat signifikan antara pendidikan dalam keluarga terhadap kepribadian muslim siswa, dapat dilihat dalam uraian tabel 6 berikut ini:

Tabel 6. Korelasi Sederhana Pendidikan dalam Keluarga dengan Kepribadian Muslim Siswa Correlations

\begin{tabular}{|c|c|c|c|}
\hline \multicolumn{2}{|c|}{ Indikator Aspek } & $\begin{array}{l}\text { Kepribadian } \\
\text { Muslim Siswa }\end{array}$ & $\begin{array}{c}\text { Pendidikan } \\
\text { Dalam Keluarga }\end{array}$ \\
\hline \multirow[t]{3}{*}{$\begin{array}{l}\text { Kepribadian } \\
\text { Muslim Siswa }\end{array}$} & $\begin{array}{l}\text { Pearson } \\
\text { Correlation }\end{array}$ & 1 & $.632^{* *}$ \\
\hline & Sig. (1-tailed) & & .000 \\
\hline & $\mathrm{N}$ & 120 & 120 \\
\hline \multirow{3}{*}{$\begin{array}{l}\text { Pendidikan } \\
\text { Dalam } \\
\text { Keluarga }\end{array}$} & $\begin{array}{l}\text { Pearson } \\
\text { Correlation }\end{array}$ & $.632^{* * *}$ & 1 \\
\hline & Sig. (1-tailed) & .000 & \\
\hline & $\mathrm{N}$ & 120 & 120 \\
\hline
\end{tabular}




\section{Deskriptif Data Regresi Ganda Variabel Keteladanan Guru dan Pendidikan dalam Keluarga terhadap Kepribadian Muslim Siswa MTs Pondok Pesantren Al-Husainy Kota Bima}

Diperoleh nilai $\mathrm{R}$ adalah 0,633. Nilai $\boldsymbol{K D}$ ( $\boldsymbol{R}$ Square) yang diperoleh adalah $0,401 \times 100 \%=\mathbf{4 0 , 1} \%$ yang dapat ditafsirkan bahwa secara simultan keteladanan guru dan pendidikan dalam keluarga memiliki pengaruh yang sedang karena nilai kontribusi sebesar 40,1 \% terhadap kepribadian muslim siswadan 59,9 \% lainnya dipengaruhi oleh faktor-faktor lain. Adapaun gamabar datanya dapat dilihat dalam jabaran Tael 7 sebagai berikut:

Tabel 7. Regresi Ganda Variabel Keteladanan Gurudan Pendidikan dalam Keluarga terhadap Kepribadian Muslim Siswa Model Summary

\begin{tabular}{|c|c|c|c|c|}
\hline Model & R & R Square & Adjusted R Square & Std. Error of the Estimate \\
\hline 1 & $.633^{\mathrm{a}}$ & .401 & .391 & 4.184 \\
\hline
\end{tabular}

a. Predictors: (Constant), pendidikan dalam keluarga, keteladanan guru

\section{Pembahasan Penelitian}

Hasil analisaketeladanan guru terhadap kepribadian muslim siswa menghasilkan koefisien korelasi $r$ product-moment sebesar 0,549. Telah signifikansi terhadap nilai koefisien korelasi tersebut diperoleh nilai Sig. (1tailed $)=0.000$, yang menyatakan tidak terdapat pengaruh ditolak, hal ini menunjukkan antara keteladanan gurudankepribadian muslim siswaadalah signifikan, artinyaterdapat hubungan positif dan signifikan antara keteladanan guru terhadap kepribadian muslim siswa di MTS Al-Husainy Kota Bima NTB.

Adapun pada model analisa regresi yang menunjukkan nilai koefisien determinasi $(K D)=R$ Square $\mathrm{X} 100 \%=0,302 \times 100 \%=30,2 \%$ yang keteladanan guru memiliki pengaruh yang sedang karena nilai kontribusi sebesar 30,2 \%, terhadap kepribadian muslim siswadan 69,8\% lainnya dipengaruhi oleh faktor-faktor lain diluar kepribadian muslim siswa, berarti bahwa setiap peningkatan satu unit skor keteladanan guru akan mempengaruhi peningkatan skor kepribadian muslim siswa sebesar 0,279. Koefisien korelasi $r$ product-moment antarapendidikan dalam keluargaterhadap kepribadian muslim siswasebesar 0,632, telah signifikansi berarti hipotesis nol ditolak, hal inimenunjukkan bahwa antara pendidikan dalam keluargaterhadap kepribadian muslim siswasignifikan, artinyaterdapat hubungan positif antarapendidikan dalam keluargaterhadap kepribadian muslim siswa.

Hasil penelitian ini sejalan dengan yang telah dikemukakan bahwa, secara garis besar ada 3 faktor yang mempengaruhi kepribadian muslim siswa, pertama faktor Biologis dan kedua faktor social dan ketiga faktor Kebudayaan. Faktor biologis itu dari keturunan atau pembawaan yang dibawa sejak lahirsiswa sedangkan faktor dari sosial mulai dari lingkungan sekolah, keteladanan guru, 
pendidikan dalam keluarga, sarana dan pra sarana, dan hal-hal lain yang dapat mempengaruhi kepribadian muslim siswa. Keteladanan guru teramasuk salah satu yang dapat mempengaruhi kepribadian muslim seorang siswa, karena siswabelajar langsung pastinya akan mengikuti keteladanan guru yang diterapkan dan tentunya ada perbedaan mendasar antara keteladanan guru disekolah islam dengan keteladanan di sekolah umum. Perbedaan mendasar diantaranya siswa diajarkan praktek agama setiap hari dimana siswa mengikuti program-program yang telah disusun dengan baik selama berada disekolah, sehingga kehidupan siswa diatur mulai dari pertama masuk sekolah hingga pulang kembali, sedangkan sekolah selain sekolah islam hanya mengatur duniawi siswa ketika berada di sekolah.

Kaitan antara keteladanan guru terhadap kepribadian muslim siswa di MTs Al-Husainy, Kota Bima, NTB ada kaitan yang signifikan, dikarenakan keteladanan guru telah teruji akan menghantarkan siswa untuk menjadi siswa yang berkepribadian muslim, maka dari itu pengelola sekolah dan yayasan sepatutnya menjaga keteladanan guru serta meningkatkan kualitas pembelajaran agar siswa dapat berkepribadian muslim lebih baik sehingga mampu bersaing secara karakter di dunia global nantinya. Pendidikan dalam keluarga termasuk salah satu yang dapat mempengaruhi kepribadian muslim siswa, karena orangtua adalah seseorang yang sering berinteraksi dengan siswa terutama dalam hal mentransformasi perilaku baik sehari-hari, sehingga orangtua dituntut untuk menyampaikan dan mencontohkan semua prilaku baik dengan baik, dan tentunya mencontohkan prilaku baik dengan berbagai cara, sehingga dengan cara-cara tersebut siswa akan menyerap dan mengikuti langsung dengan baik dan akan berdampak signifikan terhadap kepribadian muslim siswa yang baik. Pendidikan dalam keluarga di di MTs Al-Husainy, Kota Bima, NTB memiliki pengaruh yang signifikan terhadap kepribadian muslim siswa, maka dari itu orangtua sebaiknya menjaga dengan baik cara meningkatkan kualitas kepribadian agar bukan hanya pandai mentrasformasi ilmu tetapi mampu memberikan tauladan yang baik kepada siswa, sehingga siswa bukan hanya memiliki kepribadian yang baik tapi memiliki wawasan ilmu agama yang mumpuni.

\section{Penutup}

Berdasarkan hasil temuan penelitian yang telah dikemukakan sebelumnya mengenai hubungan antara Keteladanan Guru dan Pendidikan dalam Keluarga terhadap Kepribadian Muslim Siswa, dapat diambil beberapa kesimpulan sebagai berikut: 1) Terdapat pengaruh yang positif dan signifikan antara keteladanan guru terhadap kepribadian muslim siswa di MTs Al-Husainy Kota Bima. 2) Terdapat pengaruh yang positif dan signifikan antara pendidikan dalam keluarga terhadap kepribadian muslim siswa di MTs Al-Husainy Kota Bima. 3) Terdapat pengaruh yang positif dan signifikan antara keteladanan guru dan pendidikan dalam 
keluargasecara bersama-sama terhadap kepribadian muslim siswa di MTs AlHusainy Kota Bima. Dengan demikian, diharapkan pimpinan yayasan sebagai pengelola dan manajer di MTs Al-Husainy hendaknya mempertahankan Keteladanan Guru, dan mengembangkan hal-hal yang dianggap kurang, pimpinan yayasan selalu bersinergi dengan kepala sekolah agar visi dan misi tetap terjaga dan tujuan yayasan dapat dicapai sesuai apa yang diharapkan para pendiri yayasan. Agar keteladanan guru sesuai dengan perkembangan zaman, pimpinan yayasan perlu mengadakan studi banding ke pesantren-pesantren yang telah teruiji kualitasnya, serta mengadakan pelatihan-pelatihan kepada ustadz-ustadzah asrama agar bisa menjalankan keteladanan perilaku dengan baik untuk memberikan pengutan kepribadina muslim dalam diri seorang siswa dilingkup satuan pendidikan khusus di Pondok pesantren MTs Al-Husainy Kota Bima.

\section{DAFTAR PUSTAKA}

Departemen Pendidikan dan Kebudayaan. Kamus Besar Bahasa Indonesia. Jakarta: Balai Pustaka. Edisi ke II.1994.

Djamarah, Bahri Syaiful. Guru dan Anak Didik dalam Interaksi Edukasi. Jakarta: Rineka Cipta, 2000.

Jalaluddin.Teologi Pendidikan. Jakarta: Raja Grafindo Persada, 2001.

M Usman Najati. Al-Qur'an Dan Ilmu Jiwa.Bandung: Pustaka, 1997.

Marimba, D. Ahmad. Pengantar Filsafat Pendidikan Islam. Bandung: PT AlMa'arif, 1980.

Miri Jamaluddin. Pendidikan Anak dalam Islam. Jakarta Pustaka Amani, 2002.

Mukhotim El Moekry. Membina Anak Beraqidah Kokoh. Jakarta: Wahyu Press, 2004.

Purwanto, Ngalim. Ilmu Pendidikan: Teoritis dan Praktis. Bandung: Remaja Karya, 1988.

Qomar, Mujamil. Meniti Jalan Pendidikan Islam.Yogyakarta: Pustaka Pelajar, 2003.

Ulwan, NashihAbdullah. Pendidikan Anak Dalam Islam. Jakarta: Pustaka Amani, 1995.

Umar, Umar. Pengantar Profesi Keguruan. Rajawali Press, 2019.

Zuhairini dkk. Filsafat Pendidikan Islam.Jakarta: Bumi Aksara, 1995. 